\title{
Structure and distribution of glandular trichomes in three species of Bignoniaceae
}

\author{
Fabíola Fernandes Paiva de Castro FRÓES ${ }^{1}$, Thália do Socorro Serra GAMA², Ana Carla FEIO³, \\ Diego DEMARCO², Ana Cristina Andrade de AGUIAR-DIAS ${ }^{4^{*}}$ \\ 1 Universidade Federal Rural da Amazônia/ Museu Paraense Emílio Goeldi, Programa Pós-graduação em Botânica, Av. Perimetral 1901, 66077-530 Belém, PA, Brasil. \\ 2 Universidade de São Paulo, Instituto de Biociências, Caixa Postal 11461, 05508-090, São Paulo, SP, Brasil. \\ 3 Universidade Federal de Viçosa, Departamento de Biologia Vegetal, 36570-000 Viçosa, MG. \\ ${ }^{4}$ Universidade Federal do Pará, Instituto de Ciências Biológicas, Av. Perimetral, 2501, 66077-530, Montese, Belém, PA, Brasil. \\ * Corresponding author: acaaguiar@yahoo.com.br
}

\section{ABSTRACT}

Glandular trichomes play a major role in the morphological characterization of the Bignoniaceae. Due to their great diversity of forms and functions, this study aimed to inventory the glandular trichomes present in the aerial vegetative axis of Amphilophium magnoliifolium, Martinella obovata and Stizophyllum riparium, analyze their structure and register the participation of ants in these plants. Fresh samples from the nodal region, petiole and from medium to apical regions of the leaflet blade were fixed and processed according to usual methods in light and scanning electron microscopies. The glandular trichomes found were: peltate, capitate, stipitate, and patelliform/cupular. Peltate trichomes are the most abundant ones and present the most uniform distribution. Patelliform/cupular trichomes occur at specific regions, such as prophylls, leaflet blade and nodal regions. Martinella obovata is the only species that presents capitate and stipitate trichomes, which are widely distributed along the entire aerial vegetative axis. Ants were found in all species, mainly at nodal regions. The occurrence of the capitate-type trichome is reported for the first time to the genus.

KEYWORDS: Bignonieae, Nectaries, Secretory structures, Stipitate trichome.

\section{Estrutura e distribuição de tricomas glandulares em três espécies da família Bignoniaceae}

\section{RESUMO}

Tricomas glandulares desempenham papel importante na caracterização morfológica de Bignoniaceae e, devido à grande diversidade de formas e funçóes que esses tricomas apresentam, o objetivo desse estudo foi inventariar os tricomas glandulares presentes no eixo vegetativo aéreo de Amphilophium magnoliifolium, Martinella obovata. e Stizophyllum riparium, bem como analisar sua estrutura e registrar a participação de formigas nessas espécies. Amostras frescas da região mediana à apical das lâmina foliolar, pecíolo e nó foram fixadas e processadas de acordo com os métodos usuais para microscopia de luz e eletrônica de varredura. Os tricomas glandulares encontrados nas espécies foram: peltados, capitados, estipitados e pateliformes/cupuliformes. Dentre esses tipos o mais abundante foi o tricoma peltado, apresentando também uma distribuição mais uniforme que os demais. Os tricomas pateliformes/cupuliformes estavam em regiōes mais específicas, como profilos, lâmina foliolar e na região nodal. Martinella obovata foi a única espécie que apresentou os tricomas capitados e estipitados, amplamente distribuídos ao longo de todo eixo vegetativo aéreo. Em todas as espécies foram encontradas formigas, principalmente nas regióes nodais. A ocorrência do tricoma capitado é relatada pela primeira vez para o gênero.

PALAVRAS-CHAVE: Bignonieae, Estruturas secretoras, Nectários, Tricoma estipitado. 


\section{INTRODUCTION}

Due to their diversity of forms and functions, trichomes represent important taxonomic characters for the recognition of certain genera, even when the plant is in the vegetative state (Seibert 1948; Fahn 1979; Theobald et al. 1979). Trichomes may be segregated in two major groups, glandular and non-glandular (Theobald et al. 1979). Depending on exudate composition, trichomes may receive functional denominations, like nectaries, which produce nectar, and colleters, which secrete mucilage (Fahn 1979). Glandular trichomes are widely found among the 21 genera of the Bignoniaceae (Nogueira et al. 2013).

Nectar-producing trichomes located on vegetative organs - i.e. extrafloral nectaries (EFNs) - are present in $90 \%$ of the Bignoniaceae genera (Elias and Gelband 1976). Several authors (Rivera 2000b; Nogueira et al. 2013; Gama et al. 2013) have shown that these nectaries are trichomes that have a large secretory head. Extrafloral nectaries usually have an intense relationship with insects, particularly ants, which are attracted by the secreted energetic resource (Koptur et al. 1998; Heil and McKey 2003; Oliveira and Freitas 2004). This is a common event in species of tribe Bignonieae (Elias and Gelband 1976; Elias 1983). There are reports on an indirect relationship between these nectaries and the protection against herbivory, by means of the action of the visiting ants against the herbivores (Vesprini et al. 2003; Oliveira e Freitas 2004).

The anatomy of glandular trichomes in the Bignoniaceae has been the object of several studies (Subramanian and Inamdar 1989; Rivera 2000a, 2000b; Nogueira et al. 2013). However, little is known about the morphology and distribution of these characters in tribe Bignonieae. In view of their ecological and taxonomic value, this study aimed to inventory glandular trichomes present in the aerial vegetative axis of Amphilophium magnoliifolium (Kunth) L.G. Lohmann, Martinella obovata (Kunth) Bureau and K. Schum. and Stizophyllum riparium (Kunth) Sandwith, as well as to analyze their structure and participation of ants in these species.

\section{MATERIALS AND METHODS}

Collections of botanical material and field observations were performed from June through December 2012. The presence of glucose in the exudate was determined using glucostrips (Glicofita Plus ${ }^{\circledast}$, Accu-Chek Active ${ }^{\circledast}$ - F. HoffmannLa Roche Ltd.(C). Ants that visited the studied plants were collected and stored in 70\% ethyl alcohol for ulterior taxonomic analysis.

Voucher specimens were deposited in the João Murça Pires Herbarium under numbers: MG 201780, MG 201781 and MG 201782. For the anatomical study, fresh samples of the first and third nodes, leaflet blade, petiole and petiolule of Amphilophium magnoliifolium (Kunth) L.G. Lohmann, Martinella obovata (Kunth) Bureau and K. Schum. and Stizophyllum riparium (Kunth) Sandwith were collected at the Parque Ambiental de Belém Utinga (Belém Utinga Environmental Park), Belém city, Pará state, Brazil (S $\left.01^{\circ} 23^{\prime} 13^{\prime \prime}-01^{\circ} 26^{\prime} 02^{\prime \prime} \mathrm{W} 48^{\circ} 23^{\prime} 50^{\prime \prime}-48^{\circ} 6^{\prime} 47^{\prime \prime}\right)$. The collected material (leaflet blade, petiole and nodal regions) was fixed in FAA (formaldehyde - absolute acetic acid - 70\% ethyl alcohol) (Johansen 1940), in 2.5\% glutaraldehyde prepared in a $0.1 \mathrm{M}$ phosphate buffer $\mathrm{pH} 7.3$, and in neutral buffered formalin (Lillie 1965).

Samples that proceeded anatomical analyses were dehydrated with tertiary butyl alcohol for histological paraffin embedding (Paraplast Plus ${ }^{\oplus}$, Sigma-Aldrich, Germany) (Johansen 1940) and with ethyl alcohol for hydroxyethyl methacrylate embedding (Leica ${ }^{\circledast}$ Historesin; solutions prepared according to manufacturer recommendations) (Gerrits and Smid 1983). Transverse and longitudinal sections were obtained with a rotary microtome (Leica RM 2245, Nussloch, Germany). Sections of paraffin-embedded samples were stained with astra blue and safranin (Gerlach 1969), while those embedded in hydroxyethyl methacrylate were stained with toluidine blue (O'Brien and McCully 1965). Permanent glass slides were mounted in synthetic resin (Permount, New Jersey, USA) and photomicrographs were obtained with a photographic microscope (Axiolab Zeiss model A1, LLC, USA) with a coupled Canon digital camera.

For the scanning electron microscopy study, samples stored in $70 \%$ ethanol were isolated and dehydrated in an ethyl series, critical-point dried with $\mathrm{CO}_{2}$ (Emitech model K-850, Quorum Technologies, UK), mounted on metallic stubs and sputtercoated with a $20 \mathrm{~nm}$-thick layer of gold for $150 \mathrm{~s}$, under a 25 $\mathrm{mA}$ current in an Emitech equipment (model K-550) (Robards 1978). Image capture was performed in a scanning electron microscope (LEO ZEISS, model 1450VP, Oberkochen, Germany), JEOL JSM 5000LV at 20kV with 600dpi.

\section{RESULTS}

\section{Field observations - visitors}

The presence of ants could be noticed in all studied species. In Martinella obovata, ants belonged to genus Cephalotes (Figure 1A) and subfamily Myrmicinae (Figure 1B), and visited the aerial vegetative axis, especially the petiolar region (Figure 1A) and the abaxial surface of the leaflet blade (Figure 1B). In Amphilophium magnoliifolium, ants belonged to genus Crematogaster (Figures 1C and D) and were concentrated in the axillary region near prophylls, where a cluster of glands could be observed by the naked eyed. These glands were anatomically identified as cupular trichomes (Figure 1D). In this region, the presence of ants was more intense than in 


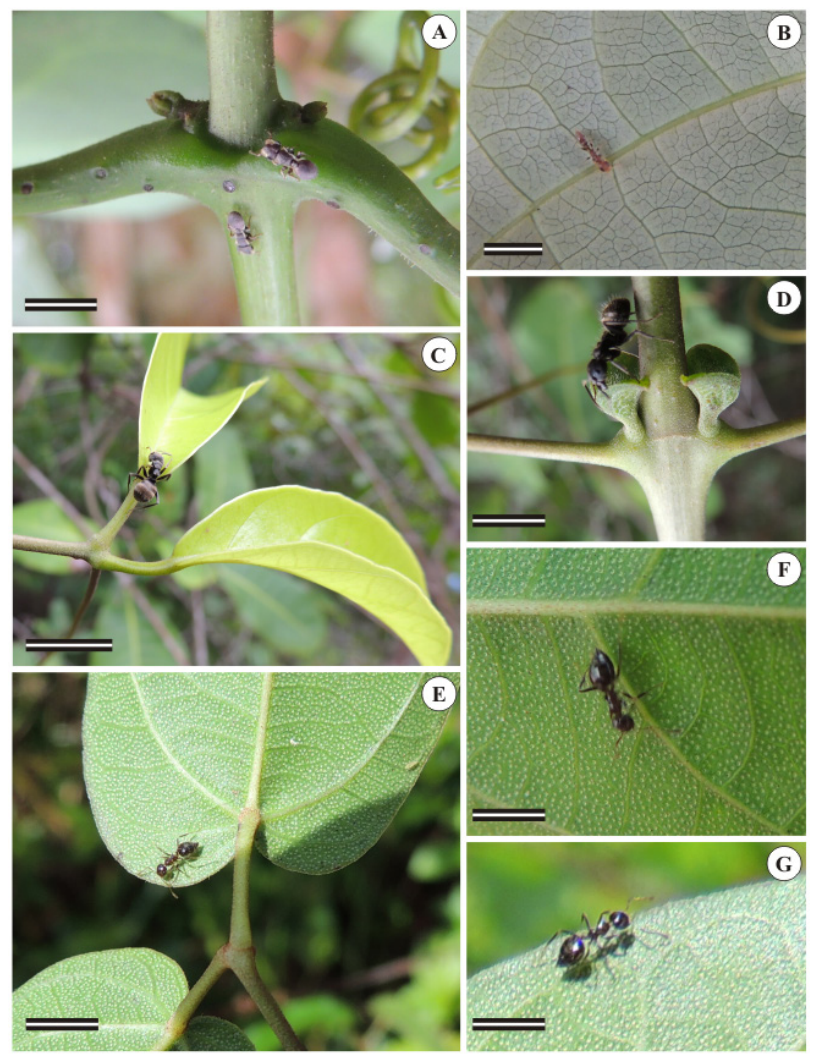

Figure 1. Ants foraging leaflet blade, petioles and prophylls of axillary buds. $\mathbf{A}$ and $\mathbf{B}$ : Martinella obovata. C and D: Amphilophium magnoliifolium. E, F, G: Stizophyllum riparium. A: notice patelliform trichomes at nodal and petiolar regions. B: ant from subfamily Myrmicinae on the leaf abaxial surface. $\mathbf{C}$ and D: ants from genus Crematogaster on the prophylls of axillary buds. $\mathbf{E}, \mathbf{F}$ and G: ants from subfamily Dolichoderinae on leaf abaxial surface in S. Riparium; notice the clear dots, which are called "pellucid glands". Scale bars $=1 \mathrm{~cm}$.

the nodal region. In Stizophyllum riparium, ants belonged to subfamily Dolichoderinae (Figures 1E, F and G). Despite the occurrence of a number of pellucid glands, which could be easily noticed on the abaxial surface of the leaflet blade in the form of translucent dots (Figures 1E, F and G), overall no intense flux of ants could be observed, in comparison with the other plants.

In all studied species, patelliform/cupular trichomes secrete nectar, as evidenced by the positive reaction in the glucostrips showed by the orange color displayed after contact with the secretion.

\section{Morphology}

Three different types of glandular trichomes were visualized along the aerial vegetative axis of the three studied species. Trichomes belong to the following morphotypes: (1) peltate, (2) capitate/stipitate, and (3) patelliform/cupular (Table 1).

\section{Peltate Glandular Trichome}

The peltate-type trichome possesses a stalk, which is usually formed by two cells, and a large multicellular secretory head (Figure 2A). This type of trichome is present in all studied species (Table 2), but with morphological variation (Figures $2 \mathrm{~A}-\mathrm{G}$ ), some of them being round-shaped (Figure $2 \mathrm{H}$ ) and concave (Figures 2I-K), like in M. obovata, or convex (Figure 2 $\mathrm{L}-\mathrm{M})$, like in A. magnoliifolium and S. riparium. Both morphs can be observed along the trichome secretory activity, but at the end of this phase the senescent trichome shows a flat aspect (Figure 2A).

The stalk usually consists of two cells (Figures 2A-D), but it may also be formed by up to five cells, as in S. riparium, in which it presents from three to five cells (Figures 2E, I-J) and is also multiseriate (Figure $2 \mathrm{~K}$ ). Among the studied species, $S$. riparium trichomes have the largest secretory head, which is formed by numerous cells (Figure 2L), while in $A$. magnoliifolium the head of the peltate trichome morphotype is formed by six cells only (Figures $2 \mathrm{M}$ and $\mathrm{N}$ ).

Table 1. Distribution of glandular trichome morphotypes in organs of the studied species [Pt: petiole; Ptl: petiolule; LIb (ab): abaxial leaflet blade; Llb $(\mathrm{ad})$ : adaxial leaflet blade]

\begin{tabular}{|c|c|c|c|c|c|c|c|}
\hline \multirow[b]{2}{*}{ Type } & \multirow[b]{2}{*}{ Species } & \multicolumn{6}{|c|}{ Location } \\
\hline & & Pt & Ptl & $\begin{array}{c}1^{\text {st }} \\
\text { node }\end{array}$ & $\begin{array}{c}3^{\text {rd }} \\
\text { node }\end{array}$ & $\begin{array}{l}\text { Llb } \\
(a b)\end{array}$ & $\begin{array}{l}\text { Llb } \\
(\mathrm{ad})\end{array}$ \\
\hline \multirow{3}{*}{ Peltate } & M. obovata & & & & $X$ & $X$ & $X$ \\
\hline & S. riparium & & $x$ & $x$ & $x$ & $x$ & $x$ \\
\hline & A. magnoliifolium & & $x$ & $\mathrm{X}$ & $x$ & $\mathrm{X}$ & $X$ \\
\hline $\begin{array}{l}\text { Capitate/ } \\
\text { Stipitate }\end{array}$ & M. obovata & $x$ & $X$ & $X$ & $X$ & $\mathrm{X}$ & $X$ \\
\hline \multirow{3}{*}{$\begin{array}{l}\text { Patelliform/ } \\
\text { Cupular }\end{array}$} & M. obovata & $x$ & & $x$ & $x$ & $\mathrm{X}$ & \\
\hline & S. riparium & & & & & $X$ & \\
\hline & A. magnoliifolium & & & $X$ & $X$ & $X$ & \\
\hline
\end{tabular}

Table 2. Presence of glandular trichomes - types: peltate, patelliform/cupular $(\mathrm{p} / \mathrm{c})$ and capitate/stipitate - in Amphilophium magnoliifolium (Kunth) L.G. Lohmann, Martinella obovata (Kunth) Bureau and K. Schum. and Stizophyllum riparium (Kunth) Sandwith.

\begin{tabular}{lccc}
\hline \multirow{2}{*}{ TYPE } & \multicolumn{3}{c}{ SPECIES } \\
\cline { 2 - 4 } & M. obovata & S. riparium & A. magnoliifolium \\
\hline Peltate & Present & Present & Present \\
Patelliform/Cupular & Present & Present & Present \\
Capitate & Present & Absent & Absent \\
Stipitate & Present & Absent & Absent \\
\hline
\end{tabular}




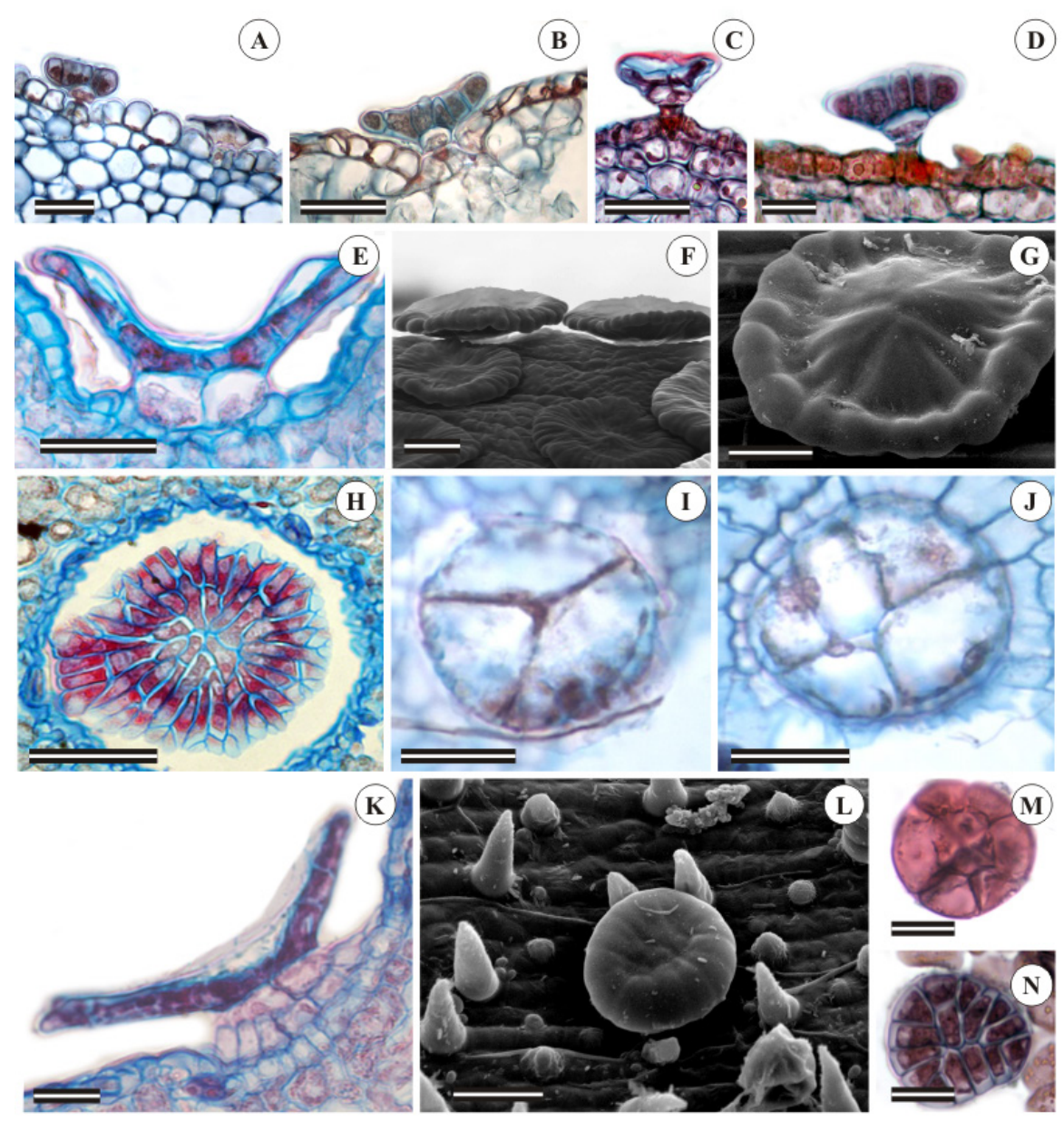

Figure 2. Morphological diversity of peltate trichomes located along the aerial vegetative organs of Amphilophium magnoliifolium (A-D and M-N), Martinella obovata $(\mathbf{H})$ and Stizophyllum riparium (E-G and $\mathbf{I}-\mathbf{L})$. A-E: trichome longitudinal view evidencing the varied number of secretory cells distributed along the secretory head. I and J-N: paradermal section. E: concave aspect of the invaginated trichome. F: notice the high trichome density. I-J: different number of cells that may form the trichome secretory head. $\mathbf{K}$ : two-cell-layered stalk in S. riparium trichomes. Scale bars $=20 \mu \mathrm{m}$

\section{Capitate and Stipitate Glandular Trichomes}

The simultaneous occurrence of capitate (short) and stipitate (long) trichomes was observed only in M. obovata (Table 2). The stalk of capitate trichomes is formed by two cells (Figure 3A), while the secretory head presents eight cells. The secretory cells possess dense cytoplasm and are coated by a thick cuticle (Figures $3 \mathrm{~A}$ and $\mathrm{B}$ ).

The distribution of stipitate trichomes is homogenous along the analyzed organs (Figures 3C and D; Table 1), except on the first node, in which a higher trichome density is observed on the axillary bud region (Figure 3C).

Stipitate trichomes present a structure similar to that of the capitate ones, but are composed of a stalk formed by four to five cells that elongate along trichome development (Figure $3 \mathrm{E})$ and a secretory head formed by four cells that are coated by a thin cuticle (Figures $3 \mathrm{E}$ and F).

\section{Patelliform/Cupular Glandular Trichomes}

The patelliform/cupular morphotype is visualized in all studied species (Table 2), both types being found in the same organs (Table 1). These trichomes are multicellular and can be flat-shaped - patelliform - (Figures 4A-E) or cup-shaped - cupular - (Figures 4F-I). Fungal hyphae are visualized on the trichome surface (Figures 4E, J and $\mathrm{K}$ ).

The stalk can be formed by two largely-vacuolated isodiametric cells (Figure 4F) or by one to two layers of cuboid cells (Figures 4B-D and L). The epidermis of the secretory head is uniseriate and palisade-arranged (Figure 4B), and its cells present dense cytoplasm and an evident nucleus. A thin cuticle delimitates the subcuticular space that stores the secretion (Figure $4 \mathrm{G}$ ), which is liberated through cuticle rupture (Figures $4 \mathrm{C}-\mathrm{E}$ and $\mathrm{J}$ ). The number of secretory cells is variable: it may be 35 or more (Figures $4 \mathrm{~B}$ and $\mathrm{L}$ ). 


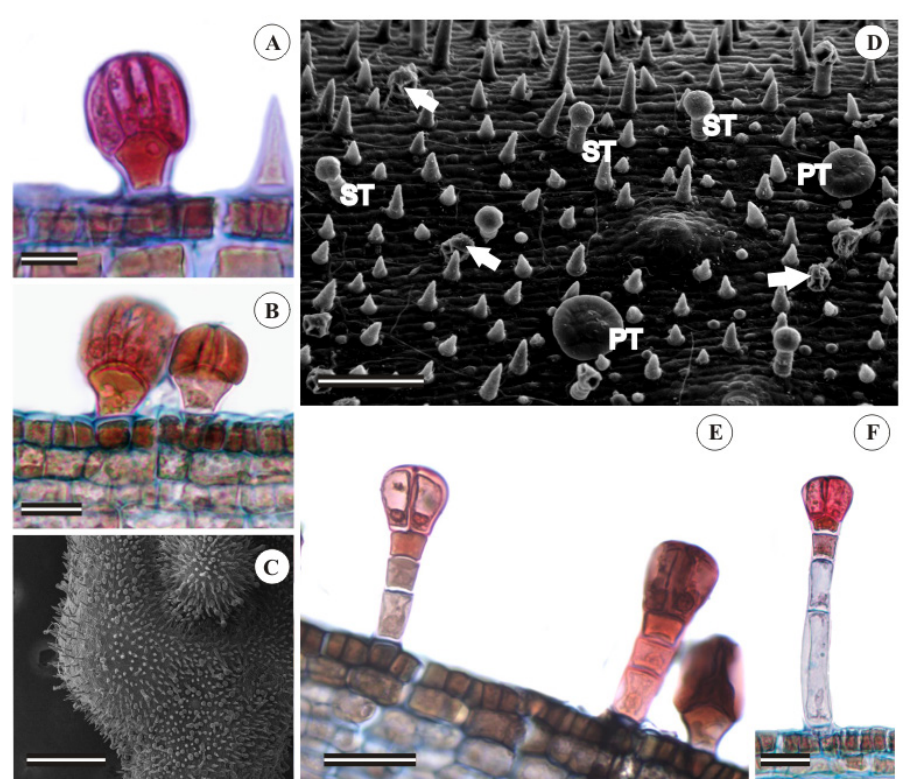

Figure 3. Capitate and stipitate trichomes in Martinella obovata. A-B and E-F: light micrographs. C and D: scanning electron micrographs. A: trichomes densely distributed on the first node. A and B: capitate trichomes. $\mathbf{C}$ and $\mathbf{D}$ : distribution of glandular trichomes; notice in $\mathbf{D}$ the distribution of capitate trichomes (arrow), stipitate trichomes (ST) and peltate trichomes (PT). E: stipitate and capitate trichomes. F: stipitate trichome. Scale bars $=20 \mu \mathrm{m}$.
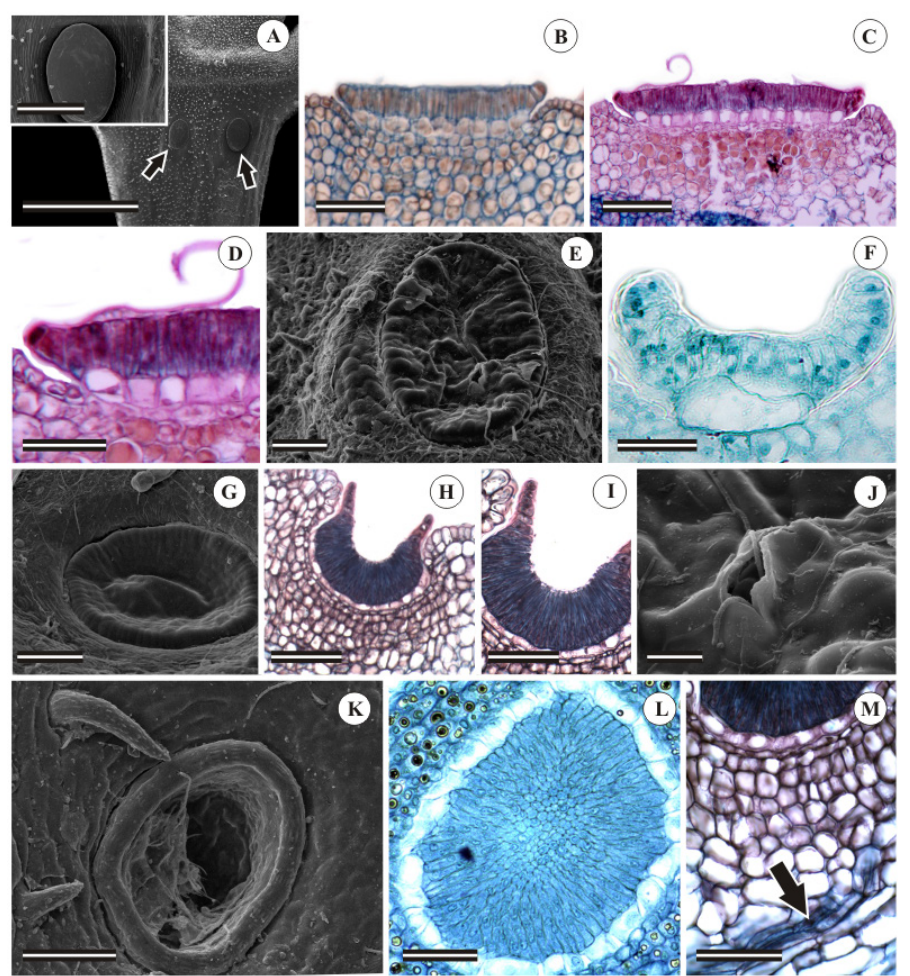

Figure 4. Patelliform/cupular trichomes in Martinella obovata (A-E, G, J-K), Stizophyllum riparium (F) and Amphilophium magnoliifolium (H-I, L-M). A-D: patelliform trichome. A: notice the location of the trichome at the nodal position. B-D: cuboid stalk cells. D: detail of stalk cells. C-E: ruptured cuticle. F: singlecelled stalk. G: distended cuticle due to accumulation of secretion. H-I: invaginated concave trichome. J: notice fungal hyphae. K: damaged trichome, possibly due to predator attack. L: frontal view; notice the number of cells composing the secretory head. M: phloem vascularization near the sixth cell layer beneath epidermis (arrow). Scale bars $=20 \mu \mathrm{m}$. 
Although patelliform/cupular trichomes are not vascularized, vascularization is visualized in the parenchymatous region near the trichome base (Figure 4M).

\section{DISCUSSION}

The glandular trichomes in Amphilophium magnoliifolium, Martinella obovata and Stizophyllum riparium were identified as morphotypes peltate, capitate, stipitate, patelliform and cupular (sensu Nogueira et al. 2013). Due to the diversity of glandular trichomes in the tribe, our analyses confirm the reports of several authors that evidenced the taxonomic value of these structures (Bureau and Schumann 1897; Seibert 1948; Gentry 1980; Vilhena-Potiguara et al. 2012; Nogueira et al. 2013; Gama et al. 2013).

Peltate trichomes are frequently found in members of the Bignoniaceae (Seibert 1948), especially in all species of tribe Bignonieae (Nogueira et al. 2013). These data corroborated those of the study by Ogundipe and Wujek (2004), who analyzed 12 Bignoniaceae genera and found peltate trichomes in all species. However, morphological variations among peltate trichomes may occur, and therefore subtypes can be found (Seibert 1948). Such variations are seen in S. riparium, as the secretory head of the peltate trichome in this species is one of the largest ones among the studied representatives.

All three species present many trichomes. In $A$. magnoliifolium, they are more representative in the regions analyzed in this study, such as the first and third nodes, leaflet blade, petiole and petiolule; thus being in accordance with the analyses performed by Nogueira et al. (2013), in which the Amphilophium species showed the highest densities when compared with Pyrostegia and Stizophyllum species.

In addition to observations regarding the amount of trichomes, the morphology of capitate trichomes, which is vast, was also assessed. Capitate trichomes can be structurally divided in two groups: uni- and multicellular; they may also be subdivided in two subtypes: short and long, the latter being the most common (Metcalfe and Chalk 1950).

In this study, long trichomes were considered stipitate, while the short ones were regarded as capitate. For capitate trichomes to be designated as such, stalk length must be larger than half the head length (Abu-Asab and Cantino 1987), which is the criterion adopted in the present work. Stipitate trichomes have been reported to several Bignoniaceae species (e.g. Adenocalymma adenophorum, A. trichocladum, Cuspidaria sceptrum, Fridericia erubescens, Mansoa hirsuta, Manaosella cordifolia, Martinella obovataNogueira et al. 2013). However, although M. obovata has been previously studied, capitate trichomes have not been reported yet, and are therefore being reported herein for the first time to the genus. The presence of stipitate trichomes in the Bignoniaceae has been previously cited in the work by Seibert (1948), but without the report of any morphotype similar to the ones visualized in our work.

The presence of the patelliform/cupular trichomes is believed to be a symplesiomorphy of the group, since they are widely distributed in the tribe, as well as peltate trichomes, which are present in the common ancestor of the tribe (Nogueira et al. 2013). Patelliform/cupular-type trichomes are also found in some Lamiaceae, which is closely related to the Bignoniaceae (McDade and Turner 1997).

With the positive result for glucose, we confirmed that the patelliform/cupular trichomes are functionally nectaries. The presence of nectaries is common on nodal regions, leaf blade adaxial and abaxial surfaces, bracts, floral buds, calyces, corollas and fruits. When present, nectaries are abundantly concentrated on the leaf abaxial surface, usually aggregated and near the veins (Elias and Newcombe 1979). The presence of numerous EFNs is a more derived condition in the Bignoniaceae than the presence of one single large EFN (Elias and Newcombe 1979).

Presumably, defensive characters (e.g. trichomes) are selected only when the cost of their production is surpassed by the resulting defensive benefits. Thus, glandular trichomes are expected to be concentrated on parts where the loss of plant tissues is more expensive to the plant (Heil and McKey 2003). In Amphilophium magnoliifolium, the presence of clusters of nectaries on the axillary bud region would then support a protective relationship against predators, since this region possesses areas with intense meristematic activity, which brings about a high energetic cost for the plant and whose loss would, therefore, represent a great prejudice for the individual.

On $M$. obovata and A. magnoliifolium, the presence of ants on leaflets, prophylls and petiolules is much more intense than on $S$. riparium, possibly due to the low amount of patelliform/cupular trichomes in this species, in comparison with the other two species. The number of cells forming the trichome also differs: in S. riparium it is limited to a total number of 27 secretory cells, while in $M$. obovata and $A$. magnoliifolium it presents a larger number of cells.

Extrafloral nectaries play an important role in plantinsect relationships, but the trichomes may also provide defensive strategies. Stipitate trichomes, for example, may secrete a sticky substance which could be observed in species studied by Nogueira et al. (2013).

The fact that capitate and stipitate trichomes are widely distributed along the entire aerial vegetative axis of $M$. obovata may not be associated with a decreased number of EFNs, since these structures are present in a considerable amount on the petiolar region. 


\section{CONCLUSIONS}

The glandular trichomes of Amphilophium magnoliifolium, Martinella obovata and Stizophyllum riparium share common morphological features with the ones of other species in the family. We conclude that there is a proportional relationship between a higher number of patelliform/cupular trichomes and a higher presence of ants, and that these ants are probably attracted by substances secreted by the trichomes.

\section{ACKNOWLEDGMENTS}

The authors thank Dr. Felipe Vivallo, from the Laboratory of Hymenoptera of the Federal University of Rio de Janeiro, for identifying the taxa of the ant species.

\section{REFERENCES}

Abu-Asab, M.; Cantino, P.D. 1987. Phylogenetic implications of leaf anatomy in subtribe Melittidinae (Labiatae) and related taxa. Journal of Arnold Arboretum, 68: 1-34.

Bureau, E.; Schumann, K. 1897. Bignoniaceae. In: Martius, C.F.P.V. (ed.). Flora Brasiliensis.

Elias, T.S.; Gelband, H. 1976. Morphology and anatomy of floral and extrafloral nectaries in Campsis (Bignoniaceae). American Journal of Botany, 63:1349-1353.

Elias, T.S.; Newcombe, L.F. 1979. Foliar nectaries and glandular trichomes in Catalpa (Bignoniaceae). Acta Botanica Sinica, 21: 217-224.

Elias, T. 1983. Extrafloral nectaries: their structure and distribution. In: Bentley, B.L.; Elias, T.S. (eds.). The biology of nectaries. Oxford University Press, Oxford, p. 174-203.

Fahn, A. 1979. Secretory tissues in plants. Academic Press, London, 302 p.

Gama, T.S.S.; Demarco, D.; Aguiar-Dias, A.C.A. 2013. Ontogeny, histochemistry, and structure of the glandular trichomes in Bignonia aequinoctialis (Bignoniaceae). Brazilian Journal of Botany, 36: 291-297.

Gentry, A. H. 1980. Bignoniaceae: Part I (Crescentieae and Tourrettieae). Flora Neotropica, 25: 1-130.

Gerlach, G. 1969. Botanische mikrotechnik. Georg Thieme Verlag, Stuttgart, 298p.

Gerrits, P.O.; Smid, L. 1983. A new, less toxic polymerization system for the embedding of soft tissues in glycol methacrylate and subsequent preparing of serial sections. Journal of Microscopy, 132: 81-85.

Heil, M.; McKey, D. 2003. Protective ant-plant interactions as model systems in ecological and evolutionary research. Annual Review of Ecology Evolution and Systematics, 34: 425-553.

Johansen, D.A. 1940. Plant microtechnique. 2 ed. McGraw Hill, New York, 523p.
Koptur, S.; Rico-Gray, V.; Palacios-Rios, M. 1998. Ant protection of the nectaried fern Polypodium plebeium in central Mexico. American Journal of Botany, 85: 736-739.

Lillie, R.D. 1965. Histopathologic technic and practical histochemistry. 3 ed. McGraw Hill, New York, 211p.

McDade, L.A.; Turner, M.D. 1997. Extrafloral nectaries in Aphelandra: Anatomy, development and systematic implications. American Journal of Botany, 84:1-15.

Metcalfe, C.R.; Chalk, L. 1950. Anatomy of the dicotyledons. Clarendon press, Oxford, 1500p.

Nogueira, A.; El Ottra, J.H.L.; Guimarães, E.; Machado, S.R.; Lohmann, L.G. 2013. Trichome structure and evolution in Neotropical lianas. Annals of Botany, 112: 1331-1350.

O’Brien, T.P.; McCully, M.E. 1965. Polychromatic staining of plant cell walls by toluidine blue. O. Protoplasma, 9: 368-373.

Ogundipe, O.T.; Wujek, D.E. 2004. Foliar anatomy on twelve genera of Bignoniaceae (Lamiales). Acta Botanica Hungarica, 46: 337-361.

Oliveira, P.S; Freitas, A.V.L. 2004. Ant-plant-herbivore interactions in the neotropical cerrado savanna. Die Naturwissenschaften, 91: $557-570$.

Rivera GL. 2000a. Nuptial nectary structure of Bignoniaceae of Argentina. Darwiniana, 38: 227-239.

Rivera GL. 2000b. Nectarios extranupciales florales en especies de Bignoniaceae de Argentina. Darwiniana, 38: 1-10.

Robards, A.W. 1978. An introduction to techniques for scanning electron microscopy of plant cells. In: Hall, J.L. (eds.). Electron Microscopy and Cytochemistry of Plant Cells. Elsevier, New York, p.343-403.

Seibert, R.J. 1948. The use of glands in a taxonomy consideration of the family Bignoniaceae. Annals of the Missouri Botanical Garden, 35: 123-137.

Subramanian, R.B.; Inamdar, J.A. 1989. The structure, secretion and biology of nectaries in Tecomaria capensis Thunb (Bignoniaceae). Phytomorphology, 39: 69-74.

Theobald, W.L.; Krahulik, J.L.; Rollins, R.C. 1979. Trichome description and classification. In: Metcalfe, C.; Chalk, L. (eds.). Anatomy of the dicotyledons. Oxford University Press, Oxford, p.40-53

Vesprini, J.L.; Galetto, L.; Bernardello, G. 2003. The beneficial effect of ants on the reproductive success of Dyckia floribunda (Bromeliaceae), an extrafloral nectary plant. Canadian Journal of Botany, 81: 24-27.

Vilhena-Potiguara, R.C.; Aguiar-Dias, A,C.A.; Kikuchi, T.Y.S.; Santos, A.C.F.; Silva, R.J.F. 2012. Estruturas secretoras em cipód'alho (Mansoa standleyi (Steyerm.) A. H. Gentry, Bignoniaceae): ocorrência e morfologia. Acta Amazonica, 42: 321-328.

Recebido em 11/11/2014

Aceito em 11/05/2015 
